\title{
OUTRAS CASSANDRAS E AS CLASSES PERIGOSAS
}

\author{
Verônica Fabrini Machado de Almeida
}

Universidade Estadual de Campinas (UNICAMP)

\section{RESUMO}

Este texto corresponde à fala na mesa temática "Vozes Feministas", realizada no X Congresso da ABRACE (Natal, 2018). A partir do mito de Cassandra, profetisa a quem ninguém dava ouvidos, mencionada em inúmeras tragédias clássicas, desdobram-se associações com o imaginário do feminino no contemporâneo, buscando evidenciar a ligação entre este e a violência contra a mulher. Num sentido mais amplo e tendo como referência o campo das Artes, aponta-se a ligação entre patriarcado, capitalismo e fascismo e a importância revolucionária dos feminismos. Compõem o texto imagens das intervenções Liquidação de Mulheres, sob orientação da autora (Coletivo Carochinha, 2018), do programa performativo da doutoranda Elisa Abrão; Quais as Vantagens de ser mulher, investigação prática da disciplina PPGAC/UNICAMP, Escritas da Cena: Arte e Ativismo (2018); e da perfo-conferência Mujeres Violentas, direção de Cláudia Echenique, com a Boa Companhia (2011/2018).

Palavras-chave: Teatro. Feminismo. Fascismo. Imaginário. Ativismo. 
$\square$ ste texto é o registro de minha fala na Mesa Temática "Vozes Feministas", realiza$\square$ da no X Congresso da ABRACE, na cidade de Natal, em outubro de 2018. Como fala, seu conteúdo era acrescido da performance própria da oralidade e, portanto, da presença - daquele que fala e de todos que estão juntos. Da fala, fez parte a presença da audiência, atenta ou desatenta na escuta, num palpitar mais agitado por compartilhar o exposto ou o desinteresse blasé que não consegue evitar conferir mensagens no celular. Uma fala pública, ouvida entre pequenos comentários, sorrisos ou bocejos, enfim, todo um campo de energias de um grupo de pessoas - de pesquisadores em Artes Cênicas - que ocorreu em 18 de outubro de 2018. A data é precisa e desempenha um papel fundamental no contexto desta fala: entre o primeiro e o segundo turnos de uma eleição fraudada que nos deixou e ainda nos deixa atônitos, dado o avassalador crescimento de fundamentalismos, fascismos e, como não poderia deixar de ser, machismo violento.

Impossível negar que os resultados da eleição marcariam fundo todo o país. Em especial, todos os artistas, pesquisadores e professores em Artes da Cena sofreram um golpe imediato com a extinção do Ministério da Cultura - uma das primeiras medidas do (des)governo que se abateu sobre nós. Essa localização temporal e espacial faz parte fundamental desta fala e busca indagar sobre a urgente e necessária colaboração e engajamento entre a pesquisa acadêmica e os movimentos sociais; afinal, para se "Celebrar a Diversidade" (tema desta X ABRACE), primeiro é preciso que ela verdadeiramente exista e seja respeitada, ouvida, dignificada, para que não sejam apenas palavras mortas num paper em revistas especializadas e qualificadas como Qualis A. Esse preâmbulo tem esse sentido: manter presente esse momento e essa aflição, esse desejo de ação concreta no mundo. Mas vamos às palavras, afinal, A revolução será feminista, ou não será!

Mais do que um convite, estar presente nessa mesa temática, "Vozes Feministas", foi um desafio para aquele momento. Conversar sobre teatro e feminismo inevitavelmente traz para a discussão a questão da arte e do ativismo, da arte como ativismo ou para que serve a arte em tempos de fascismo e fundamentalismo.

Nesses momentos, algumas de nós, mulheres, nos sentimos como se tivéssemos a garganta de Cassandra - aquela cujas profecias lúcidas encontravam ouvidos moucos. A voz da mulher, quando e como é ouvida? O primeiro grande esforço é fazer-se ouvir e fazer-se crer. Termos como mansplaining, manterrupting e gaslighting ${ }^{1}$ já migraram dos manuais feministas para inúmeras piadas, memes e muitos outros chistes.

1 Sugiro a leitura de Kosak, Pereira e Inácio (2018). 

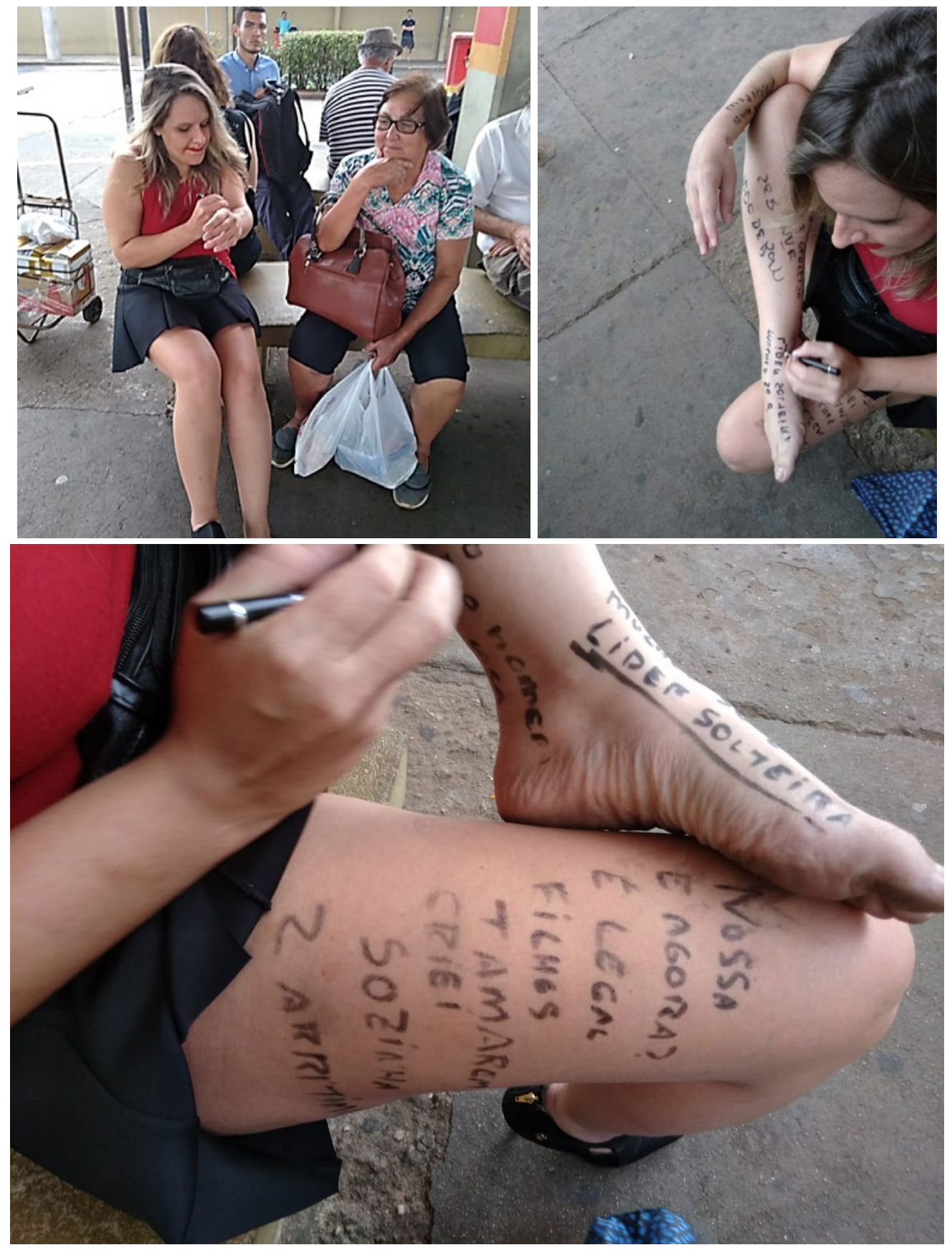

Imagens 1, 2 e 3: Programa Performativo de Elisa Abrão, Qual a Vantagem de ser Mulher? (Arte e Ativismo, PPG/AC, UNICAMP, 2018).2 Terminal de Ônibus de Barão Geraldo. Na foto de Isabella Amaral, a performer Ana Flávia Felice.

2 Sobre a ação, comenta sua autora, Elisa Abrão: "Na realização do programa performativo, éramos seis mulheres, Ana Flávia, Luzia, Geovana, Adriana, Lis e Elisa, que, vestidas predominantemente de vermelho e preto, calçando somente em um dos pés um salto alto e com maquiagens borradas, ríamos e cantávamos pela rua. Reunir essas mulheres fez a ação ter elementos da pesquisa de cada uma, que criava modulações específicas à ação. Existiam momentos em que as relações transitavam por instantes de intimidade nos quais olhávamos nos olhos das mulheres, nos reconhecíamos e escutávamos as respostas. Parecia que a 
Voltemos à Cassandra, pois, afinal, estamos num espaço das Artes da Cena - espaços que tendem a instaurar imaginários -, e nele minha filiação primeira é o teatro. Uma arqueologia do nome Cassandra, ${ }^{3}$ ainda que num rápido passeio por dicionários etimológicos disponíveis na rede, condensa a ambivalência do feminino no imaginário que já veremos se afirmar nas inúmeras tragédias que citam sua figura. Cassandra é a que brilha sobre os homens, a que protege os homens - Kassa (ramera) e andros (homem) -, a que auxilia o homem, a que brilha como homem, a que se destaca entre os homens, irmã dos homens, la que enreda a los hombres. Nota: $\mathrm{O}$ que a define é sua relação com o masculino.

Conta o mito (Graves, 2004) que, certa vez, após um dia de festejo no templo de Apolo, Cassandra adormeceu ao lado de seu irmão Heleno. Durante o sono, duas serpentes passearam sobre seus corpos e, nesse passeio, passaram sua língua sobre os órgãos do sentido dos irmãos. As serpentes passeiam assim, pois é próprio delas sentir o espaço com a língua, descobrir o mundo com a língua. E foi assim, agraciados pela língua da serpente em seus olhos, ouvidos, nariz e boca que a ambos foi conferido o dom da profecia. No entanto, a profecia de Cassandra era diferente daquela de Heleno. Enquanto o irmão interpretava o futuro a partir de sinais exteriores, como o voo dos pássaros, as formas das nuvens ou outros hieróglifos da natureza, Cassandra profetizava em delírio, inspirada pelo deus, possuída, incorporada por Apolo. Apolo desejou Cassandra, pois é próprio dos deuses desejar os mortais. Mas ela recusa seu corpo ao deus. Sua primeira falha trágica, hybris de mortal: como ousar negar seu corpo mortal a um deus imortal? Não... é não? Quem ela pensa que é? Então, Apolo cospe em sua boca e, com isso, Ihe tira o dom da persuasão, fazendo com que ninguém nunca acreditasse nas suas previsões. Triste sina de Cassandra, a certeza do vaticínio e o desespero do descrédito. Imensa solidão essa de ver o presente com clareza, de prever o futuro, ver suas previsões se realizarem e, ao mesmo tempo, ser impotente frente aos acontecimentos por não ser ouvida, por ser tida como louca, histérica, possuída.

pergunta gerava uma cumplicidade, e com muitas mulheres foi possível permanecer conversando, e os temas eram predominantemente sobre o fato de sermos mulheres. Participaram da ação Isabella Amaral, fazendo registro, e Ariana, que, com roupas cotidianas e mais afastada do grupo, ouvia os relatos após nossas conversas com as mulheres. [...] Existiu também algo que transitava por um não conseguir responder, por exemplo, as respostas 'não lembro', 'melhor ser homem' e/ou 'acho que não tem vantagem'. Percebo que a pergunta cria uma certa movimentação de contrafluxo e convida a conversa sobre o ato de ser mulher. [...] $\mathrm{O}$ ato de fazer o programa performativo As vantagens de ser mulher permitiu olhar para a vida de mulheres em um espaço cotidiano que é o terminal de ônibus. Nos aproximamos do que Thompson, citado por Eleonora Fabião, aponta dos momentos que 'a arte entra na vida', e ele ainda afirma 'a questão motivadora', muito mais do que 'o que é arte?', será 'o que é vida?'" (Fabião, 2013, p. 8).

3 Disponível em: http://etimologias.dechile.net/?Casandra; http://portrasdonome.blogspot. com/2016/09/cassandra.html; https://www.significadodonome.com/cassandra/; https://edisciplinas.usp. br/pluginfile.php/409973/mod_resource/content/2/demgol_pt.pdf. 
Cassandra ${ }^{4}$ é citada em diversas tragédias que chegaram até nós. Em Eurípides, nós a encontramos em Andrômaca, quando implora para que matassem Paris, pois sabia que ele causaria a destruição de Troia; em Hécuba, seu dom da profecia é mencionado e já anuncia seu fim como escrava de Agamemnon; em Electra, Cliptemnestra denuncia à filha a ousadia do pai em trazer como espólio de guerra a concubina possuída por um deus; em Ifigenia em Aulis, menciona-se sua inspiração por uma divindade. Mas é em Agamemnon, de Ésquilo, e n'As Troianas, de Eurípides, que Cassandra vai surgir como personagem ativa. Por essas peças terem atravessado o tempo e inúmeras traduções, é por meio delas que vão se fixar o caráter, os traços e os rastros de Cassandra que chegam até nós.

Cassandra inicia suas previsões com um grito.

4 A referência à Cassandra nas tragédias tem como base, além das tragédias citadas - Agamemnon (Ésquilo, 2007) e As Troianas (Eurípides, 2005) -, a dissertação de mestrado de Vinagre Pereira (2013). 


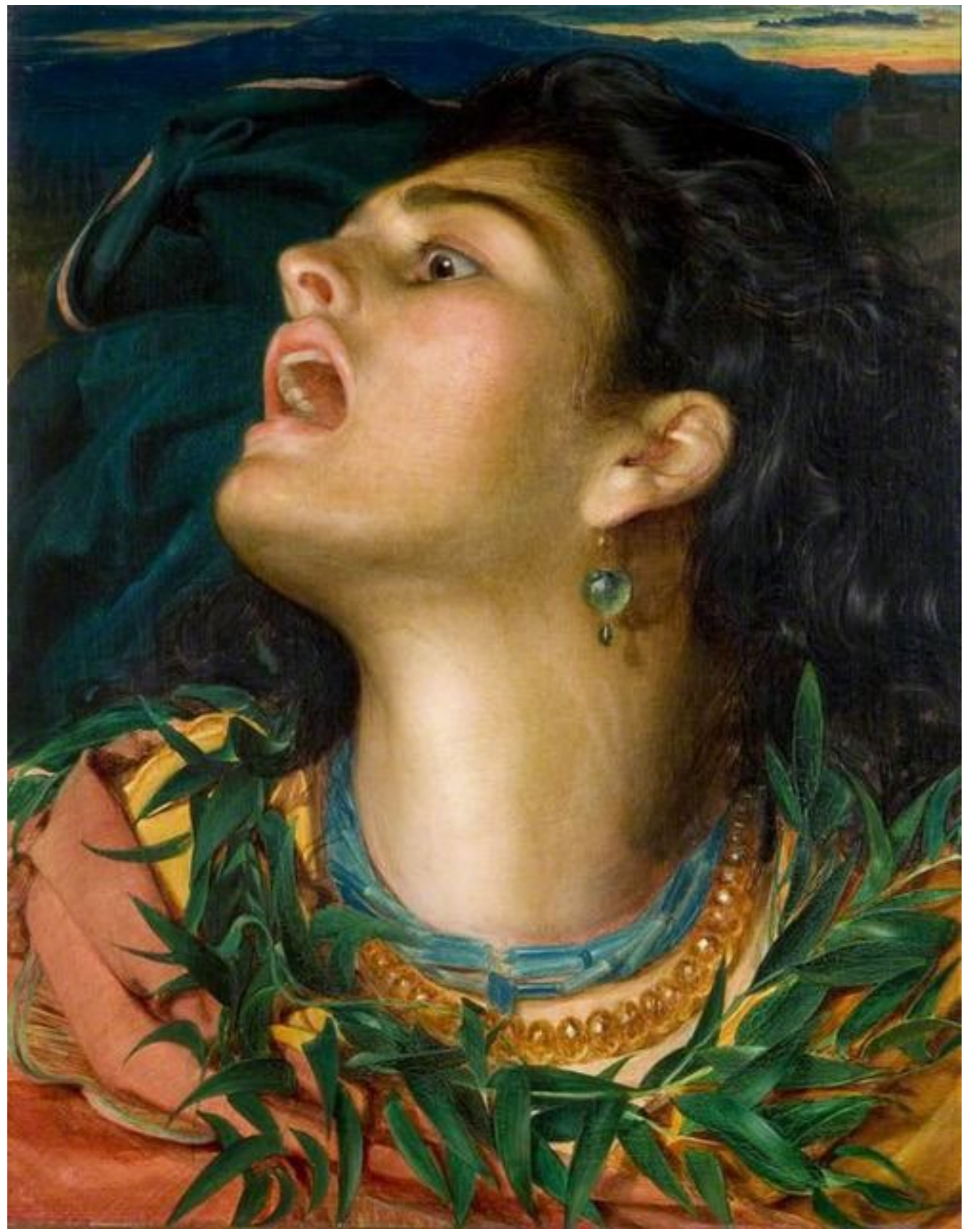

Imagem 4: Cassandra, de Frederick Sandys (1863-1864). Óleo sobre tela, Ulster Museum.

Em Agamemnon, o conhecimento de Cassandra não está limitado a esta capacidade de prever o futuro. Ela possui não só o conhecimento do passado, mesmo o que não foi vivido por ela ou por ela presenciado, como também vê o presente com aguda clareza, conseguindo estabelecer relações entre estes três tempos. Mas o descrédito nas suas palavras as torna inúteis, incapazes de mudar o destino. $\mathrm{E}$ o Coro insiste: "estás alucinada e certamente / alguma divindade te domina / entoas um canto desencantado". Aqui ela é aquela que negou o corpo ao deus e, por 
isso, perde o dom da persuasão. Cassandra prevê sua morte e as demais mortes no palácio de Agamemnon. Aqui é Apolo o principal deus que guia a clareza de suas palavras na narração do destino dos Átridas.

Outra vez, pergunto: existirá maior solidão do que possuir um conhecimento único, inclusive o da nossa própria morte, de sermos capazes de relacionar passado, presente e futuro e, apesar de tudo isso, não conseguir partilhar? Não sermos ouvidas quando a evidência da destruição está em toda a parte. Nem precisa ser profetiza para ver...

A Cassandra de Eurípides mantém a mesma solidão, a mesma desconfiança e estranheza, a descrença por parte daqueles que a rodeiam em relação às suas profecias e às suas atitudes. Mas, n'As Troianas, a falta de credibilidade não é um castigo devido a uma falta cometida, antes, é uma consequência do seu comportamento de bacante. Entra em cena um outro deus, irmão de Apolo, Dionísio. N'As Troianas, as atitudes de ménade de Cassandra acentuam a excepcionalidade de seu caráter, ao mesmo tempo em que levam à sua marginalização. Cassandra é considerada louca por aqueles que a rodeiam devido ao seu comportamento de bacante, adoradora de Dionísio. Sua loucura seria uma consequência da possessão por esse outro deus: o deus estrangeiro, deus andrógino, deus da fertilidade, da geração na terra, no Grande Feminino. Essa é uma mudança relevante de caráter, pois acentua a incorporação da dimensão disjuntiva, disruptiva desse deus. Com essa ênfase em Dionísio, Eurípides acentua a figura da profetisa como um elemento estranho, uma "vergonha" que se deve ocultar aos estrangeiros que não a conhecem. Embora aqui não se mencione a maldição de Apolo sobre Cassandra, como em Agamemnon, temos a mesma descrença por parte dos que a rodeiam. Numa, pela desobediência a Apolo (negar-lhe o corpo) e, noutra, pelo seu comportamento de bacante, de louca. Negar-se a entregar o corpo ou comportar-se como louca resulta em silenciamentos e descréditos que são ainda tão familiares às mulheres. Apesar das classificações mansplaining, manterrupting e gaslighting, ainda somos tratadas como Cassandras.

O silêncio de Cassandra. O grito de Cassandra. 


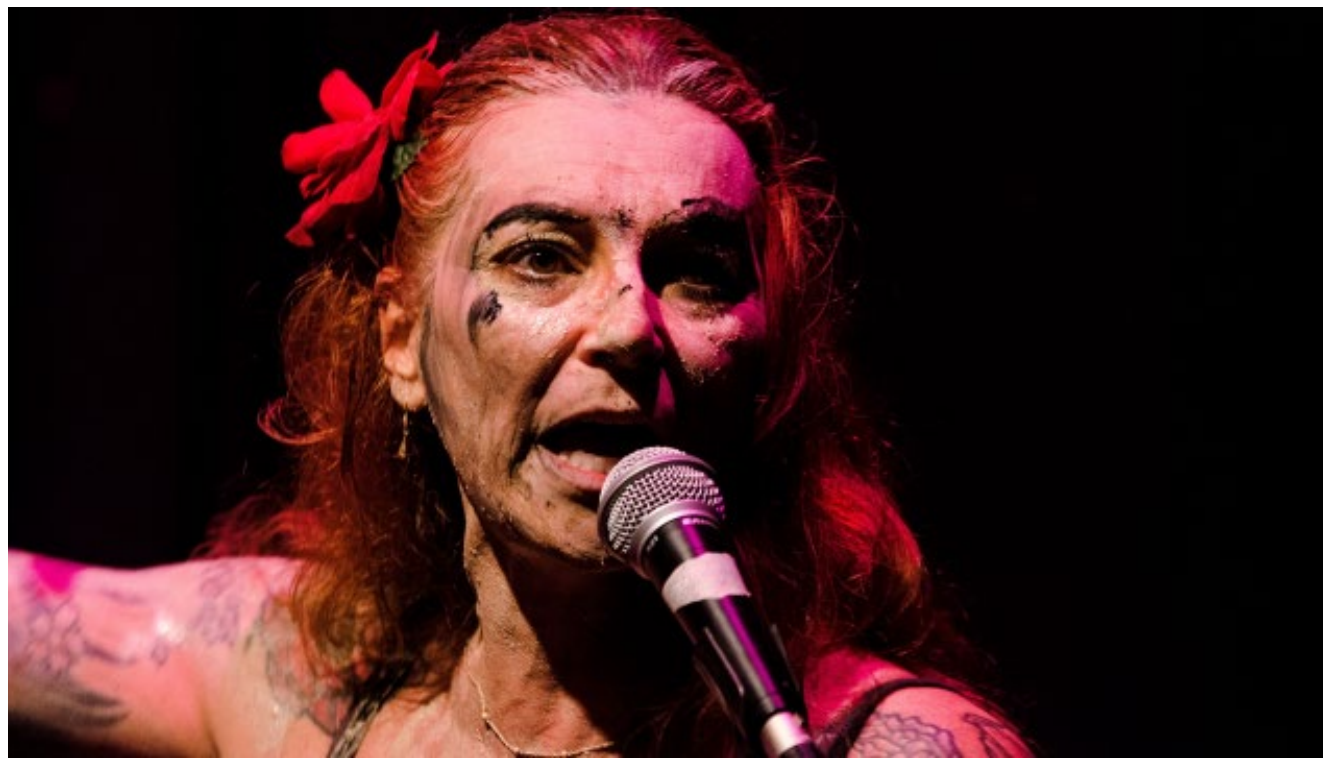

Imagem 5: Veronica Fabrini em Mujeres Violentas. Foto: Maycon Soldan (2017). Mujeres Violentas é uma perfoconferência escrita e dirigida pela chilena Cláudia Echenique, com atuação de Veronica Fabrini e Melissa Lopes (2011-2016) e, atualmente, com a participação de Ló Guimarães. Mais informações em Fabrini e Echenique (2017).

Novamente evoco a localidade e a temporalidade dessa fala, em Natal, 18 de outubro de 2018, afinal o conhecimento, como afirma Haraway (1988), é uma experiência situada, como veremos mais tarde.

A fala foi escrita logo após a manifestação \#ELENÃO, realizada em diversas cidades do país, como repúdio à candidatura de Jair Bolsonaro. No Largo da Batata, em São Paulo, estimou-se a presença de 100 mil pessoas e, na Cinelândia, no Rio de Janeiro, 25 mil. Numa entrevista à BBC Brasil, na matéria com a chamada "\#EleNão: a manifestação histórica liderada por mulheres no Brasil vista por quatro ângulos" (Rossi; Carneiro; Gragnani, 2018), Céli Regina Jardim Pinto, autora de Uma história do feminismo no Brasil e professora do Departamento de História da Universidade Federal do Rio Grande do Sul, comenta que o \#EleNão de 29 de setembro de 2018 foi a maior manifestação de mulheres da história do país:

O feminismo da minha geração era formado por mulheres acadêmicas ou de movimentos sociais. Teve muita influência na Constituição de 1988, mas era muito fechado em um grupo. Ainda por cima, era muito malvisto tanto pela sociedade mais conservadora como pela própria esquerda. [...] O que aconteceu agora foi uma popularização do feminismo. Está espraiado na sociedade. Ninguém mais pode dizer que é contra os direitos das mulheres.

A concisão poética (panfletária, equivocada?) do "ELE NÃO" se estenderia ao patriarcado e sua histórica derivação colonialista, imperialista e capitalista? Tendo a 
pensar ou a desejar que sim. As ligações entre patriarcado, colonialismo e capitalismo foram amplamente abordadas pelo feminismo decolonial de Maria Lugones, em 2014, ou mesmo em reiteradas colocações do sociólogo Boaventura Sousa Santos, desde seu crédito aos estudos feministas na conceituação das epistemologias do sul, ao seu ativismo junto aos movimentos sociais ou ao seu belo artigo dedicado à Marielle Franco, no portal Sul21, quando afirma: "Tenho defendido que vivemos em sociedades capitalistas, coloniais e patriarcais, por referência aos três principais modos de dominação da era moderna: capitalismo, colonialismo e patriarcado ou, mais precisamente, heteropatriarcado" (Santos, 2018).

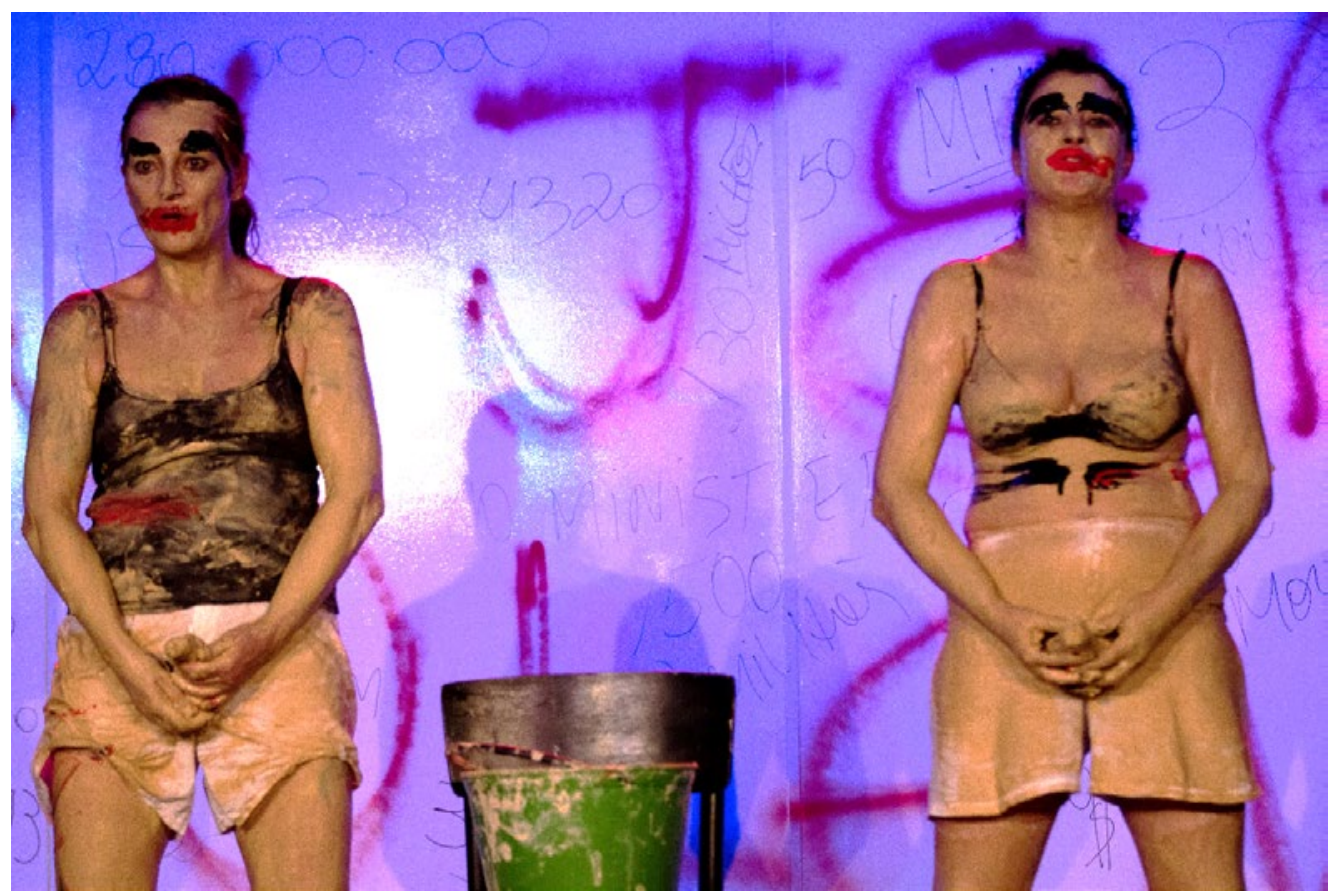

Imagem 6: Veronica Fabrini e Melissa Lopes em Mujeres Violentas. Foto: Maycon Soldan (2017).

Por sua vez, a antropóloga Rita Laura Segato é contundente ao explanar as ligações entre capitalismo e violência contra a mulher ao analisar o feminicídio em Ciudad Juárez. O capitalismo global é uma doença, uma doença fatal - e a fronteira entre México e Estados Unidos sintetiza essa imagem em sua cruel concretude: liberdade para circulação de mercadorias e proibição da livre circulação dos trabaIhadores; sucesso na acumulação de riquezas e total negação em distribuí-las; "coisificação" dos corpos e idolatria ao dinheiro. A fronteira coloca frente a frente uma das cidades com o maior número de homicídios do México, Ciudad Juárez, e uma das cidades mais seguras dos Estados Unidos, El Paso. Nas palavras da antropóloga (Segato, 2004): “La frontera entre la miséria-del-excesso y la miséria-de-la-falta es um abismo". Segato (2004, p. 75, tradução nossa) testemunha: 
Ciudad Juárez é também, significativamente, um lugar emblemático da globalização econômica e do neoliberalismo, com sua fome insaciável de ganância. A sombra sinistra que cobre a cidade, o medo constante que senti a cada noite da semana que ali estive me acompanham até hoje, mais de um mês depois do meu regresso ao Brasil. Ali se mostra a relação direta entre capital e morte, entre acumulação e concentração desreguladas e o sacrifício de mulheres pobres, morenas, mestiças, devoradas pela rede onde se articulam economia monetária e economia simbólica, controle de recursos e poder de morte.

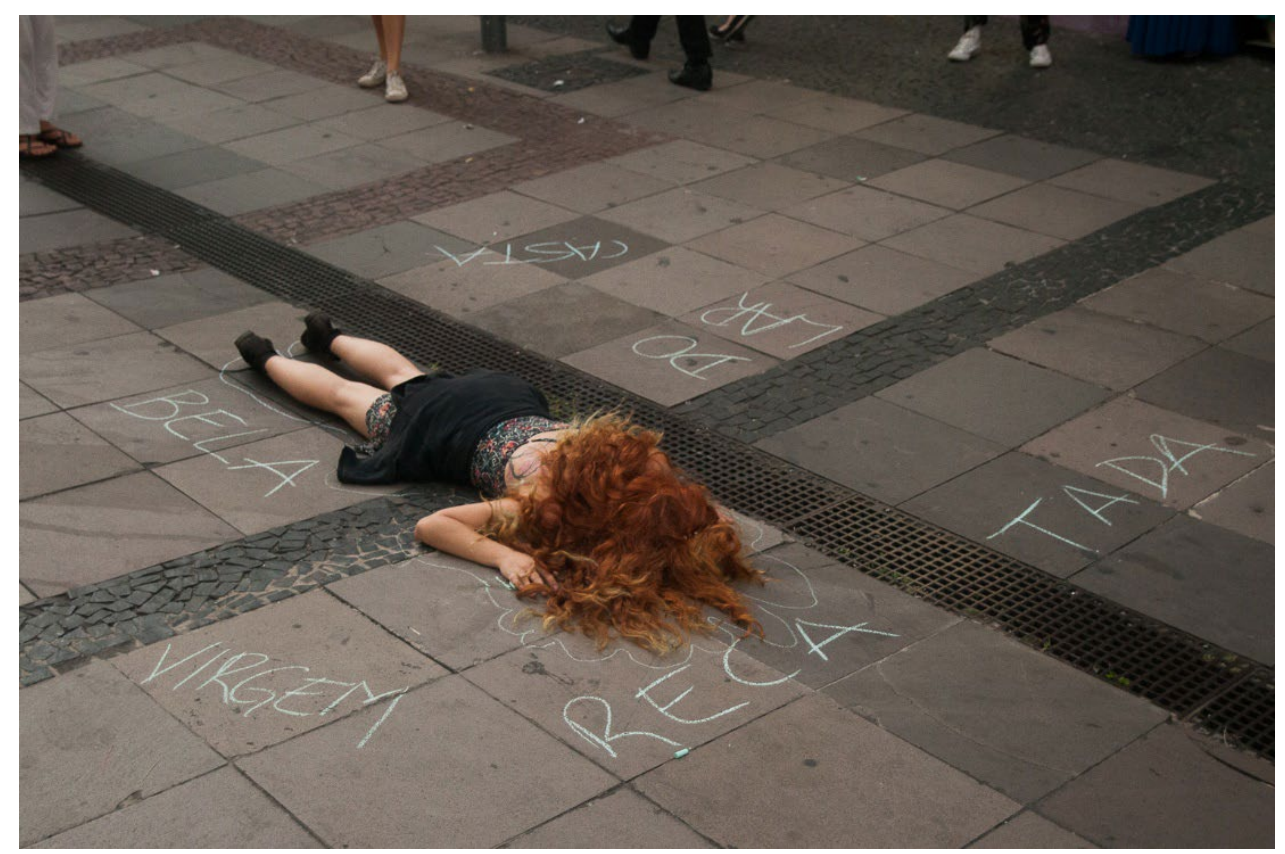

Imagem 7: Intervenção Liquidação de Mulheres, no Calçadão 13 de maio, Campinas (Núcleo da Carochinha, 2018). Performer Ana Carolina Madrigrano. Foto: Veronica Fabrini.

Terá sido esse sentido ampliado do "ele", ele-patriarcal, ele-exclusão, ele-dominação, ele-império, ele-capital, ele-morte, ele-feminicídio, epistemicídio, genocídio... - o que terá provocado a nefasta reação do horror e ódio, ódio e horror, como tão bem sintetizou Arnaldo Antunes e sua voz de baixo profundo no "desabafo" Isto não é um poema?

\author{
"no coração do Brasil" \\ fraturado \\ nesses dias \\ brutos \\ de coturnos
}

5 Disponível em: https://www.youtube.com/watch?v=4rhGdg1yHMo. Acesso em: 1 dez. 2018. 


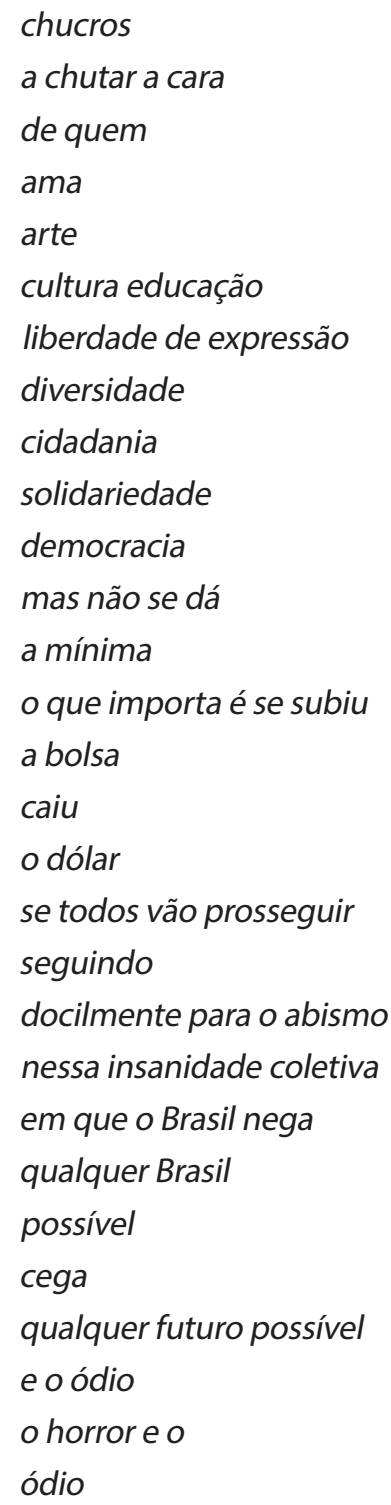

Na sequência dos fatos, com as intimidações, com o crescimento das intenções de voto para o Coiso, o antropólogo Luiz Eduardo Soares publica em sua página o texto "A barbárie está autorizada. O horror saiu do armário", divulgado também pelo portal Sul 21, em 6 de outubro de 2018. Cito:

[...] grande parte de nossas vidas é regida pelo que é invisível: emoções, afetos, expectativas, desejos, memórias, fantasias. Há também nossas crenças, valores e as ideias que produzimos ou reproduzimos. Boa parte dos veículos que dão corpo a esse mundo de coisas intangíveis são os símbolos, de que nós, antropólog@s e artistas, nos ocupamos. Uma característica chave dessa realidade virtual é que ela está imersa feito um iceberg no grande oceano que chamamos inconsciente. Os símbolos são como barcos que brilham no fundo escuro da 
noite. Quando as ondas baixam, nós os vemos, iluminados, sinalizando para nós alguma mensagem distante e obscura. Quando as ondas sobem, os barcos desaparecem no horizonte. (Soares, 2018).

O autor segue evocando dois casos dos muitos atos de violência cometidos pelos bolsonaristas: no primeiro caso, a "profanação" da placa em homenagem a Marielle Franco, vereadora do PSOL executada brutalmente com quatro tiros na cabeça. Reescrevo às vésperas de um ano de seu assassinato ainda não resolvido, apesar das evidências das ligações com as milícias e dessas com o governo. A placa, retirada de seu local de origem e assinatura de uma memória, foi partida e exibida como um troféu. No segundo caso, os torcedores do Palmeiras entoando cantos de guerra enaltecendo Bolsonaro e prometendo matar homossexuais.

O autor retoma:

[...] grande parte de nossas vidas é regida pelo que é invisível. Na política, não é diferente. Por isso, não é preciso incluir no programa de governo referências a um plano de extermínio, não é preciso apresentar publicamente um programa genocida. Não é necessário exaltar a violência e o preconceito, ou incitar o ódio, explicitamente - ainda que isso tenha sido feito. $\mathrm{O}$ que põe em circulação a barbárie não está nos argumentos racionais da candidatura ou em suas propostas de políticas públicas. A mensagem já foi passada à sociedade. $\mathrm{E} a$ mensagem se resume a uma autorização. Autorização à barbárie. A morte foi convocada. A barbárie está autorizada. O horror saiu do armário. Os espectros do fascismo estão aí, entre nós, a nos assombrar e ameaçar. Estão aí porque já existiam inclusive no espírito de alguns sujeitos que não imaginavam que pudessem ser contaminados.

Li esse texto para os estudantes assustados e profundamente tristes, na segunda-feira na qual saíram as estatísticas de segundo turno. Perguntamo-nos da importância e da responsabilidade dos artistas que trabalham com esse material poderoso e que passa tantas vezes despercebido, o invisível: emoções, afetos, expectativas, desejos, memórias, fantasias. Como são vivenciadas essas dimensões? Com qual grau de consciência? Como essas dimensões vêm sendo trabalhadas na formação de artistas? Como essa dimensão vem sendo absorvida como um tecido epistêmico singular, dotado de uma dinâmica própria e, por que não dizer, apoiada por uma "epistemologia feminista"? Luiz Eduardo Soares (2018) finaliza:

A candidatura da ultradireita autorizou a violência, a vendetta ressentida contra o que foi constituído como objeto de ódio e medo: as classes perigosas, os negros, a comunidade LGBT e todos os portadores da mudança, a mudança mítica que traz incerteza, incerteza sobretudo quanto a si mesmo. $O$ grande medo que eles têm é de si mesmos. É o medo daquele oceano noturno, que abre sua goela no fundo da noite e dá à luz o lado sombrio do sujeito. 
Sobre "as classes perigosas", gostaria de lembrar aqui um outro episódio do fascismo, evocando o fuzilamento de duas grandes figuras do teatro, na luta contra o fascismo espanhol: o primeiro, bem conhecido de todos nós, é Federico García Lorca, poeta, músico, dramaturgo - que, a propósito, privilegiava a mulher como eixo central de sua dramaturgia -, também ativista, tendo o teatro como instrumento de luta e diretor da trupe mambembe La Barraca, com a qual viajou ao longo de cinco anos, pelos vilarejos mais afastados de uma Espanha às vésperas da Guerra Civil.

Lorca era homossexual. Marica, como escreveu o dramaturgo argentino Pepe Cibrián Campoy, numa peça belíssima na qual Lorca conversa com seu assassino. Lorca é fuzilado por ser gay e revolucionário. Por ser revolucionário gay. Por ser uma classe perigosa. Porque amar outros homens não era possível. Por ser de uma outra ordem, por ser uma classe perigosa. Marica: mulherzinha, moça, desviado, invertido, homem efeminado, muito sensível. Antônimo de marica: macho corajoso. Assim é numa rápida passagem pelos dicionários na rede. Para Pepe Cibrián Campoy (2010), marica "es todo aquel que há pensado diferente". Um breve trecho do texto, extraído da página do autor:

Assassino: es tarde y ya tengo frio.

Federico:Yo também. Sera esto frio o la ilusión de perderte?

Assassino: No te entiedo y son palavras que suenan como maricuelas. Dicen mis generales, y disse queipo de llano, que eres marica, y yo acato lo dicho por generales y sobretodo, lo dicho por queipo de llano. Palabras de un marica, que no se si son palavras. Em poco rato tendrá España um maricón menos. Quieres los ojos tapados?

Federico: Prefiero estar presente.

Pergunto: nessa campanha imoral, vergonhosa e explicitamente fálica, de armas apontadas, de que têm tanto medo os fascistas? Medo de si mesmos? Medo de mulher? Medo do feminino?

A segunda pessoa que convido para estar aqui conosco, em outros planos, é uma mulher contemporânea e amiga de Lorca, mas da qual provavelmente poucxs ${ }^{6}$ de nós ouvimos falar, por se tratar de uma mulher: Agustina Gonzales Blanco, ${ }^{7}$ ela também ativista, escritora, artista, também ela de Granada. Agustina Gonzales, a Zapatera - que inspira Lorca a escrever A Sapateira prodigiosa, peça que ele denomina como "farsa violenta" e na qual questionava a moral e a política opressora.

6 Nota do Editor: A revista optou por manter as marcações neutras de gênero estabelecidas pela autora ao longo do artigo.

7 Sobre Agustina Gonzales, ver Pilar Nieva de la Paz (1993) e Enriqueta Barranco Castillo e Fernando Girón Irueste (2010). 
A sapateira era uma mulher extravagante, independente financeiramente, entrava sozinha nos cafés, se declarava feminista, funda o partido Entero (termo esotérico da teosofia). Humanista com o lema "Paz e Liberdade", interessava-se por questões como: "por que existem homens afeminados e mulheres masculinizadas?". Escrevia e colocava essas perguntas em cartazes, na vitrine de sua loja de sapatos. Em uma de suas obras, explica por que decidiu se vestir de homem e por que, em certas ocasiões, preferia parecer uma louca: porque a liberdade não estava permitida para as mulheres. Sabe-se que ela também estudava teosofia, que publicou em 1927 o livro A Lei Secreta, sobre a vida e a morte, que acreditava na reencarnação. Há referência a dois dramas escritos por ela: Quando la vida calla (Quando a vida é silenciosa, texto perdido) e Os prisioneiros do espaço. Escrevia textos futurísticos, panfletos nos quais aspirava nada menos que apagar fronteiras, criar a moeda universal; ansiava criar o Palácio de Todos, para dar hospedagem aos deserdados do mundo; registrava em uma bandeira branca apenas duas palavras: Comida e Paz, para erradicar as fomes do mundo. Agustina pintava e fazia gravuras e assinava essas obras como Amélia, como Amélia da Casa de Bernarda Alba, última peça escrita por Lorca.

Foi fuzilada em outubro de 1936, assim como Lorca, na mesma vila. Fuzilada por ser prostituta, ou lésbica, ou louca, desajustada, classe perigosa, artista, feminista e ativista. Antes de ser fuzilada, pediu clemência às estrelas. Penso hoje na poesia desse gesto, que Marielle não teve tempo de fazer. Agustina era apaixonada por astronomia.

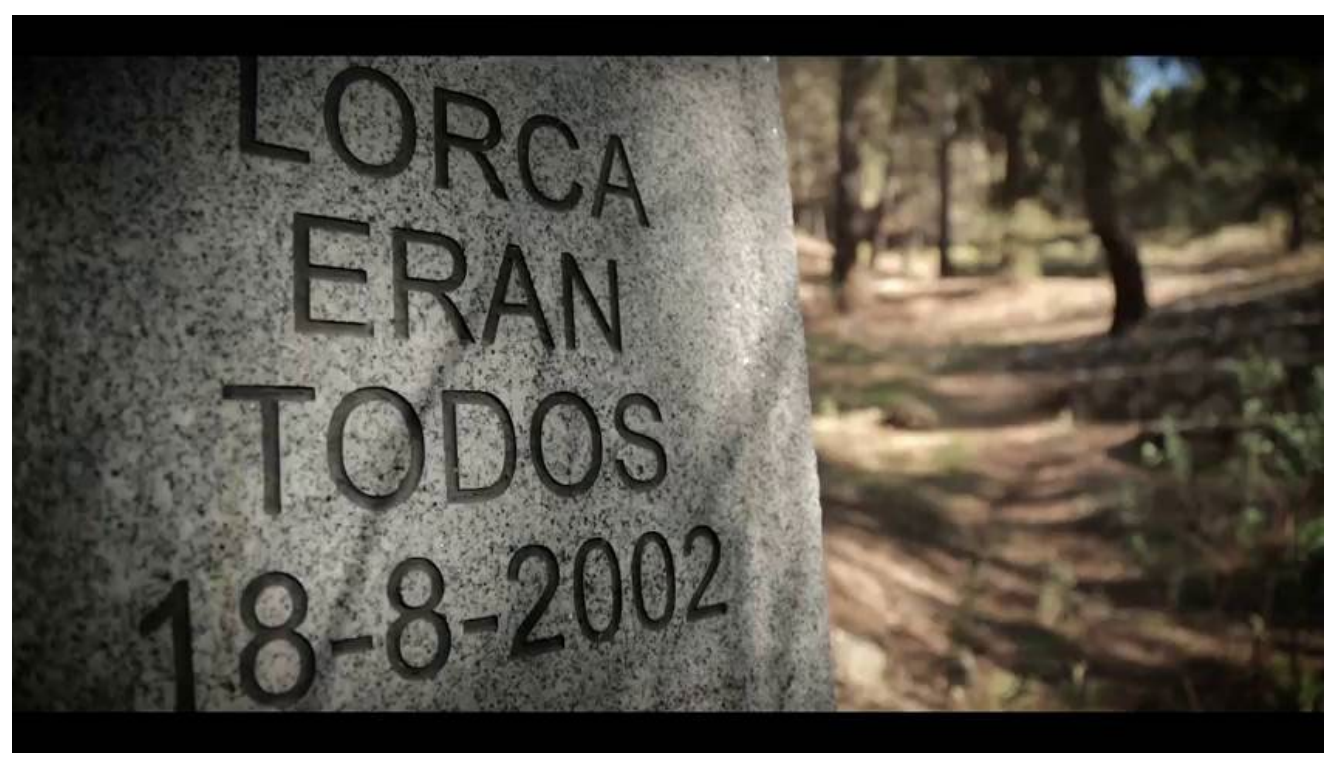

Imagem 8: Homenagem a Lorca, no possível barranco de seu fuzilamento, em Alfacar, Granada, ou o lugar onde pode ter sido enterrado junto a outros políticos executados na noite de 17 de agosto de 1936. Fonte: Almodóvar (2015).

No livro O assassinato de García Lorca (1981), Ian Gibson registra: "Trescastro exclamou: 'Eu fui um dos que tiraram García Lorca da casa dos Rosales. É só que estávamos fartos de gays em Granada. Fartos de maricas e de putas, como La Zapatera"'. 
Nem o corpo de Lorca nem o corpo de Agustina foram encontrados. Agustina era livre, ativista, anarquista e mística. No seu livro As Leis secretas, escreve como desenhava sonhos em sessões mediúnicas e de hipnose. Livre e bruxa.

Pergunto: nessa campanha imoral das eleições roubadas de 2018, vergonhosa e explicitamente fálica, de armas apontadas, de que têm tanto medo os fascistas? Medo de mulher livre? De mulher sem medo? Medo de mulher? Medo do feminino? Medo do escuro? Medo do instinto? Medo dos instintos? Medo das bruxas...

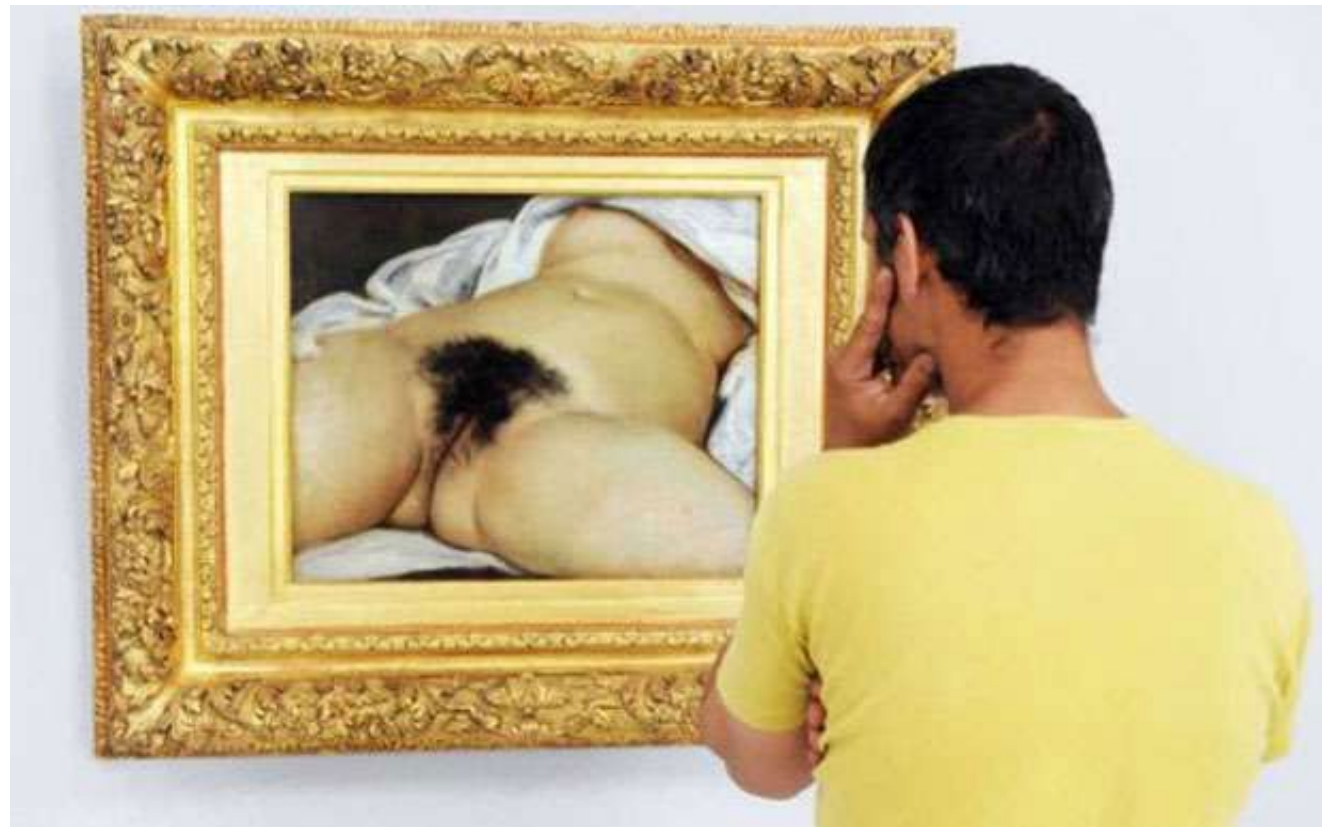

Imagem 9: Observando A origem do mundo, de Gustav Coubert. Fonte: Guyot (2013).

Numa dimensão mais profunda, arquetípica, o medo do Feminino é o medo do inconsciente, o medo da morte. Medo de si mesmo, medo dos instintos, medo da desrazão, da dissolução, da diversidade, da multiplicidade, da inconstância, do imprevisível. É nesse medo que se gera o fascismo. Por analogia, por atração, Medo do Grande Feminino, esse que é invisível, que é imaginado, pressentido, desconhecido, mas que está na base dos afetos e da memória. Nossa memória mais longínqua é feminina, pois todos nós estivemos abrigados num útero escuro e quente. Insisto e repito, como um refrão que não se deixa esquecer, as já citadas palavras de Luiz Eduardo Soares (2018):

[...] grande parte de nossas vidas é regida pelo que é invisível: emoções, afetos, expectativas, desejos, memórias, fantasias. Há também nossas crenças, valores e as ideias que produzimos ou reproduzimos. Boa parte dos veículos que dão corpo a esse mundo de coisas intangíveis são os símbolos, de que nós, antropólog@s e artistas, nos ocupamos. 
De que maneira lidamos com essa dimensão quando pesquisamos? Quando estamos em sala de aula? Em sala de ensaio? Quando criamos? Existe um modo "em feminino" de se criar? De se pensar? De conhecer o mundo e as coisas? Existe uma epistemologia feminista? Quais são suas bases? Como entender o grito de Cassandra? O delírio de Cassandra? O silêncio de Cassandra?

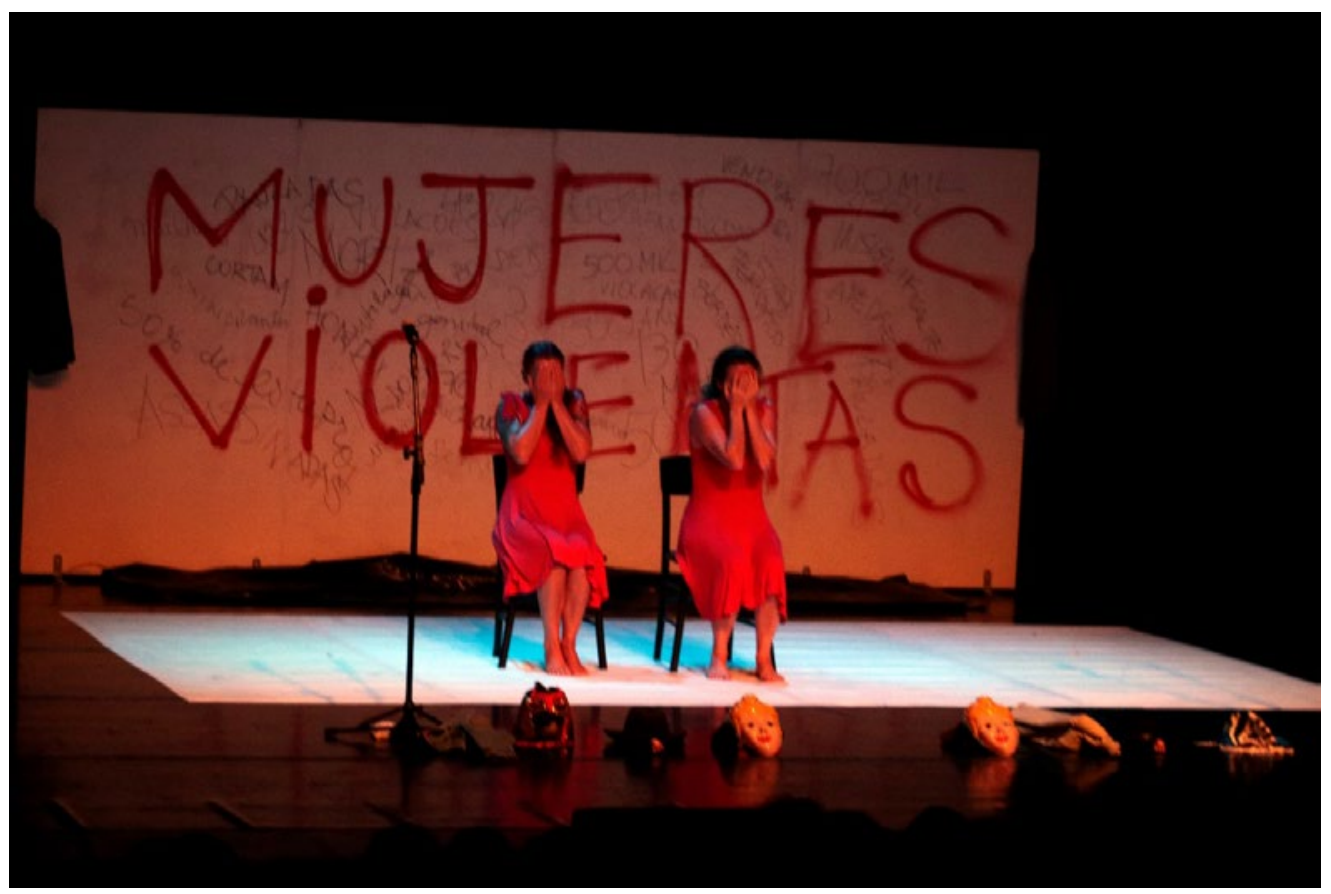

Imagem 10: Ló Guimães e Veronica Fabrini em Mujeres Violentas (2018). Foto: Nina Pires.

Numa apresentação de Mujeres Violentas em 2018, num Festival em Santa Bárbara do Oeste, havia um grupo de adolescentes assistindo à peça. Os risos e brincadeiras do início foram aos poucos dando lugar a um silêncio e escuta. Uma das meninas chorava muito e seguiu chorando até o final, quando foi conversar conosco, depois de terminada a apresentação. Contou-nos que não conseguia parar de chorar (não devia ter mais que quinze anos) e que um colega - um menino - veio abraçá-la dizendo: "Imagino que a última coisa que você poderia querer agora é o abraço de um menino. Mas me desculpe. Eu não sabia". Pequenas lembranças que fazem o teatro valer a pena.

Num salto da vida privada à vida pública, estamos de volta à nossa crise atual. Não há como escapar dela quando o tema é feminismo. Escrevi para a mesa da ABRACE antes das eleições e reescrevo hoje, mediante o aumento brutal dos casos de violência contra a mulher e de feminicídios, mediante o fino balanço geopolítico no qual não se descarta uma terceira guerra, mediante os violentos estertores do pós-capitalismo global, o crescimento global do fascismo que equivale ao crescimento do moralismo, do falocentrismo, da perseguição às classes perigosas, das 
etnias perigosas e das mulheres. Salve, Marielle (um ano de seu assassinato, e nada resolvido)! Salve, Mestre Moa!

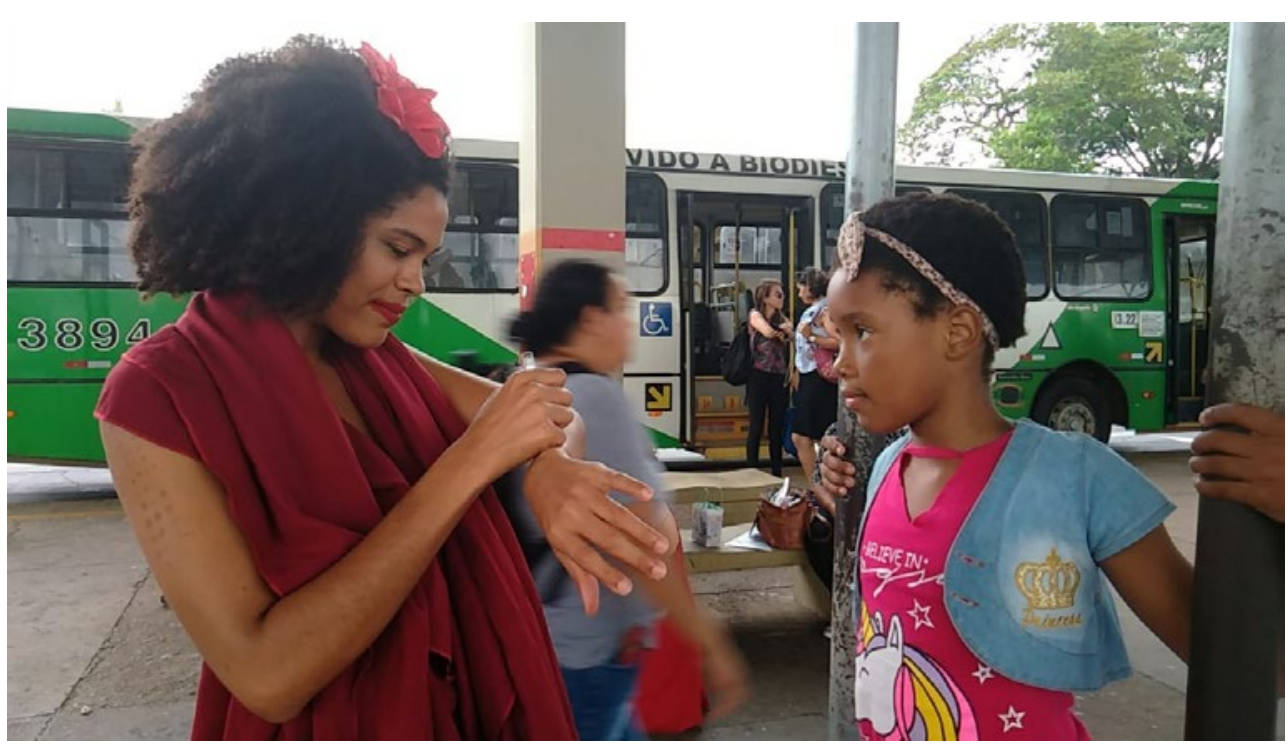

Imagem 11: Programa Performativo de Elisa Abrão, Qual a Vantagem de ser Mulher? (Arte e Ativismo, PPG/AC, UNICAMP, 2018). Terminal de Ônibus de Barão Geraldo. Na foto de Isabella Amaral,

a performer Adriana Gabriela Santos Teixeira.

Há uma linha direta que conecta patriarcado, colonialismo, imperialismo e capitalismo. Em seu livro Calibã e as Bruxas (outra vez o teatro como porta de entrada para outras reflexões!), a historiadora feminista Silvia Federici (2017) observa que, nas análises marxistas e foucaultianas sobre o capitalismo e o modo como se impôs às sociedades e aos corpos, faltava o olhar sobre o feminino. A autora então investiga o que houve com as mulheres durante a lenta e gradual instalação do capitalismo na passagem da Idade Média para a Idade Moderna e coloca a caça às Bruxas - um genocídio de imensa proporção, de milhares de mulheres - como o grande evento responsável por aniquilar a participação, a força e a resistência das mulheres. Federici aponta esse momento em que a vida em comunidade, a experiência comunitária sustentada e urdida pelas mulheres, começa a se desfazer. Essas bruxas eram lavradoras, parteiras, curandeiras, mulheres que conheciam as ervas e a natureza e que tinham principalmente autonomia sobre seus corpos, decidindo elas mesmas sobre a gravidez ou o aborto, de modo que os processos de produção estavam em pé de igualdade com a produção.

A caça às bruxas foi a estratégia para tirar das mulheres toda a autonomia de que desfrutavam. Para isso, foi fundamental o trabalho sobre os afetos e o imaginário, trabalhando no invisível terreno dos afetos, como nas Bruxas de Salém, que Artur Miller escreve em 1953, durante o macarthismo, sublinhando aqui também a questão do racismo. Qualquer semelhança não é mera coincidência. Queimavam nas 
fogueiras as "classes perigosas", queimam as formas de organização sociais comunitárias, formas de lidar com o corpo, com a vida, com o cosmos, formas de interagir em igualdade com a natureza. Diz Federici (2017, p. 334):

A caça às bruxas foi, portanto, uma guerra contra as mulheres; foi uma tentativa coordenada de degradá-las, de demonizá-las e de destruir seu poder social. Ao mesmo tempo, foi precisamente nas câmaras de tortura e nas fogueiras onde se forjaram as ideias burgueses de feminilidade e domesticidade.

Para Silvia Federici, a caça às bruxas é um mecanismo que se repete, ainda que com outras roupagens, sempre que o capitalismo passa por alguma crise e precisa se reafirmar. Como hoje, por exemplo. Em seu livro, são exemplos a perseguição e catequização dos povos nativos durante os processos coloniais na América e na África, os processos de escravidão, a Guerra Fria e, atualmente, a crescente violência contra mulheres, negros e grupos LGBT, no que ela chama de um processo de "colonização global". "Estamos acostumados a pensar na caça às bruxas como algo que já passou, mas sempre que o capitalismo bambeia, voltamos a experimentá-la. É uma história do presente", comenta a autora (Federici, 2017).

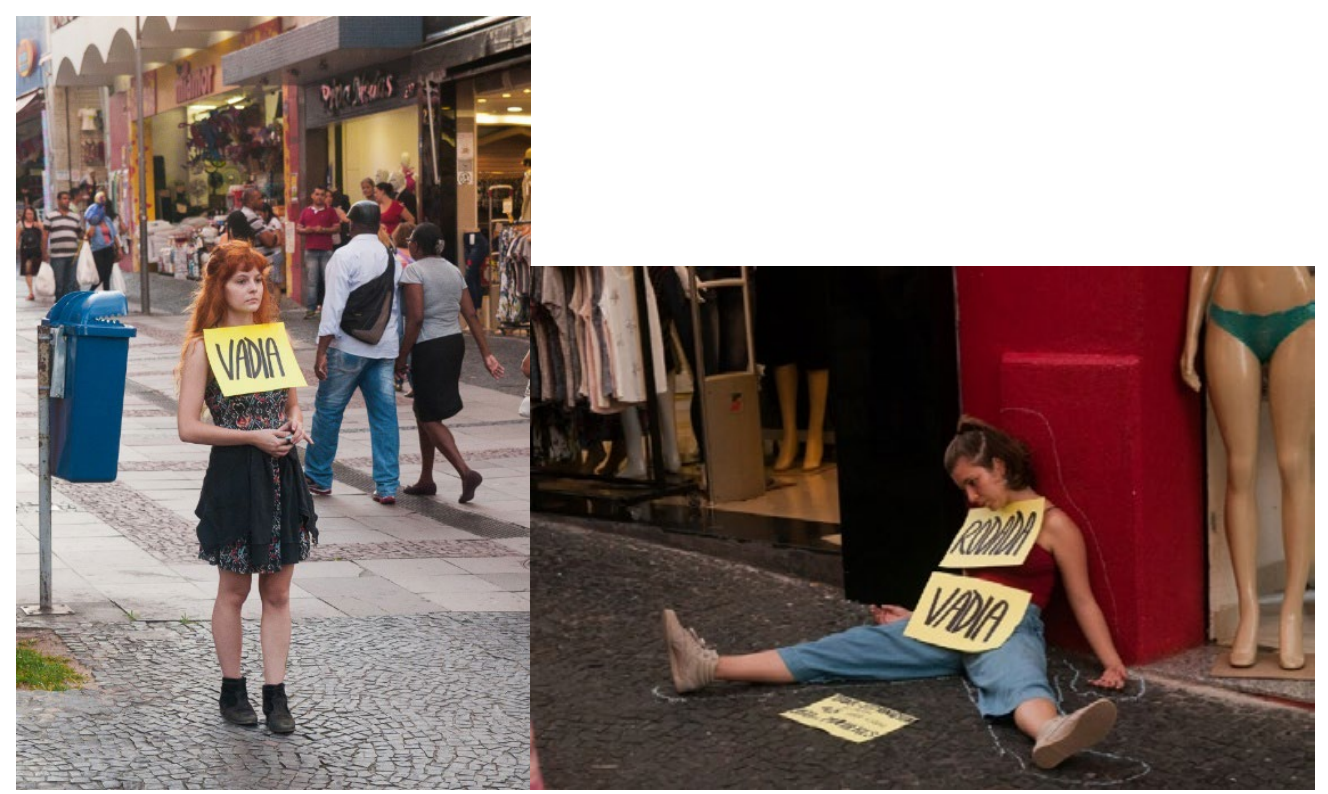

Imagens 10 e 11: Ana Carolina Madrigrano e Karen Mezza na intervenção Liquidação de Mulheres, no Calçadão 13 de maio, Campinas (Núcleo da Carochinha, 2018). Foto: Veronica Fabrini.

Há ainda um ingrediente especial nessa "cola" que liga patriarcado-colonialismo-imperialismo e capitalismo e que é fundamental para pensar as artes da cena no contexto acadêmico: o papel preponderante e hegemônico da razão. A razão se sobrepõe como único modo de acesso ao saber, deixando de lado culturas inteiras que operam por outras vias, por múltiplas vias - como a escrava Tituba, do citado 
Bruxas de Salém. A razão, filha do lluminismo, gerou e arrebanhou para junto de si todo um rol de categorias coloniais, patriarcais, racistas e heteronormativas historicamente naturalizadas. São categorias excludentes e segregadoras, arrogando-se como universais, que logo serviram como arma para um verdadeiro epistemicídio que, via de regra, não descartava também genocídios - se quisermos evocar aqui, como exemplo, as populações indígenas e negras das colônias. Saber é Poder.

Os estudos feministas são demolidores no que diz respeito à racionalidade científica, dominante nos meios acadêmicos. Denunciam a tirania dos universais (é o corpo, tão caro às artes cênicas, um dado "universal?") e a neutralidade científica, assumindo que cada pesquisador(a) é atravessado(a) por marcadores de classe, gênero, orientação sexual e raça/etnia, ou seja, todo conhecimento é, portanto, fruto de uma experiência situada. Faz-se e cria-se, conceitua-se e analisa-se desde um ponto de vista. A construção do conhecimento numa perspectiva feminista considera que a história pessoal do pesquisador está, invariavelmente, entrelaçada à sua produção acadêmica - em especial nas ciências sociais e humanas e nas artes. A esse respeito, comentam as pesquisadoras do Centro de Investigação em Ciências Sociais da Universidade do Minho, Thaís França e Beatriz Padilla:

Neste sentido, as críticas feministas avançam também, ao defender a importância do "conhecimento e experiência situada" (Haraway, 1988) que permite explicitar desde onde se faz e cria conhecimento.

[...] São de registar, igualmente, as observações que os estudos feministas fazem à prática científica como sendo uma construção social e histórica específica e que, portanto, reproduz os valores dominantes e hegemónicos de cada época. Nas palavras de Narvaz e Koller (2006, p. 648), "[a]s teorias, antes que verdades absolutas, são apenas diferentes maneiras de construir e organizar o conhecimento e referendar uma práxis legitimada por determinada comunidade científica em determinado contexto histórico". Diante de tal entendimento, não é de se espantar que numa sociedade patriarcal como a nossa as práticas de produção científica tenham arraigadas dentro de si este ranço. Consequentemente, diante de tal tradição conservadora e sexista, reproduz-se nas ciências o lugar subalterno e inferiorizado que tem sido reservado às mulheres na sociedade. (França; Padilla, 2013).

Finalizando, empresto as palavras de Margareth Rago e suas especulações sobre as epistemologias feministas como uma inseparável parceira das investigações acadêmicas em Artes Cênicas (Rago, 1998, p. 21-42). Afirma a historiadora que o feminismo, para além de uma crítica ao modo dominante de produção do conhecimento científico, propõe um modo alternativo de operação e articulação. A superação da ideia da produção de conhecimento como um processo racional e objetivo nos convoca a buscarmos novos parâmetros de processos que incorporem a dimensão 
subjetiva, emotiva e intuitiva, que busquem ultrapassar a divisão corpo/mente, sentimento/razão. Um modo feminista de investigar pede o envolvimento entre sujeito e objeto, numa mútua interação, onde não há um método pronto, onde o caminho se faz ao caminhar. Um modo de conhecer no feminino defende e assume o relativismo cultural, enfatiza a historicidade dos conceitos, assume temporalidades múltiplas. É polimorfo, polifônico e politeísta, ampliando o campo das experiências históricas, assumindo as dimensões do cotidiano, compreendendo as múltiplas implicações entre as esferas públicas e privadas, entre a cozinha e a sala.

O feminismo dá à luz a uma epistemologia da diferença na qual conhecer o mundo é pluralizá-lo. Conhecer e emergir nesse escuro e profundo mar de diferenças, entrar em contato com diferentes matrizes de entendimento, de perspectivas, sem se preocupar com unidade de sentido, mas com a unidade poética, de beleza de cada matriz. Penso que o teatro é um espaço privilegiado para o exercício e a prática dessa perspectiva, pois é o lugar por excelência da multiplicação dos olhares e sentires. Para que mundo seja como o teatro: um mundo onde caibam vários mundos.

No contexto atual brasileiro, pós-golpe, no qual cabe sublinhar o alto grau de misoginia na deposição da presidentA, é urgente assumir essa causa - a do feminismo - em todos os campos que ela atravessa. O futuro é, sem dúvida, feminista. Oxalá, assim seja!

\section{Referências}

ALMODÓVAR, Luis. Frame de vídeo. In: RUIZ MANTILLA, Jesús. A interminável busca pelos restos do poeta espanhol Federico García Lorca. El País, 28 out. 2015. Disponível em: https://brasil.elpais.com/brasil/2015/10/26/cultura/1445885173_774592.html. Acesso em: 7 set. 2018.

BARRANCO CASTILLO, Enriqueta; GIRÓN IRUESTE, Fernando. Aspectos Teosóficos del Teatro de Agustina González López y Ramón María del Valle-Inclán. Ferrolanálises: Revista de Pensamiento y Cultura, n. 25, p. 130-139, [2010]. Disponível em: http:// www.clubdeprensadeferrol.com/pdf/FA25_17.pdf. Acesso em: 7 set. 2018.

CIBRIAN, Pepe. Marica Texto. Pepe Cibrian, 17 maio 2010. Disponível em: http:// pepecibrian.blogspot.com/2010/05/marica-texto.html. Acesso em: 7 set. 2018.

ÉSQUILO. Agamemnon. Trad. Trajano Vieira. São Paulo: Perspectiva, 2007.

EURÍPIDES. Duas Tragédias Gregas: Hécuba e Troianas. São Paulo: Martins Fontes, 2005. FABIÃO, E. Programa performativo: o corpo-em-experiência. ILINX Revista do LUME, n. 4, dez. 2013.

FABRINI, Veronica; ECHENIQUE, Claudia. La presencia de las Fúrias en mujeres violentas. In: SEMINÁRIO INTERNACIONAL FAZENDO GÊNERO 11 \& WOMEN'S 
WORLDS CONGRESS, 13., 2017, Florianópolis. Anais Eletrônicos [...]. Florianópolis, 2017. Disponível em: http://www.wwc2017.eventos.dype.com.br/resources/ anais/1499447369_ARQUIVO_LAPRESENCIADELASFURIASVERSAOFINAL.pdf.

FEDERICI, Silvia. Calibã e as Bruxas. São Paulo: Elefante, 2017.

FRANÇA, Thais; PADILLA, Beatriz. Epistemologias feministas e mobilidade científica: contribuições para o debate. Configurações, n. 12, p. 47-60, 2013. DOI: 10.4000/ configuracoes.2203. Disponível em: http://configuracoes.revues.org/2203. Acesso em: 31 ago. 2018.

GIBSON, lan. O assassinato de García Lorca. Porto Alegre: L\&PM, 1981.

GRAVES, Robert. Mitos Gregos. São Paulo: Madras, 2004.

GUYOT, Pascal. Foto. In: AFP - AGENCE FRANCE-PRESSE. Especialista identifica modelo do quadro"A origem do mundo". Uai, 8 fev. 2013. Disponível em: https://www. uai.com.br/app/noticia/e-mais/2013/02/08/noticia-e-mais,140215/especialistaidentifica-modelo-do-quadro-a-origem-do-mundo.shtml. Acesso em: 07 set. 2018.

HARAWAY, Donna. Situated knowledges: the science question in feminism and the privilege of partial perspective. Feminist Studies, v. 14, n. 3, p. 575-599, 1988.

KOSAK, Mirian Maria; PEREIRA, Deivdy Borges; INÁCIO, Adriele Andreia. Gaslighting e mansplaining: as formas da violência psicológica. In: SIMPÓSIO GÊNERO E POLÍTICAS PÚBLICAS, 5., 2018, Londrina. Anais [...]. Londrina: Universidade Estadual de Londrina, 2018. Disponível em: http://www.uel.br/eventos/gpp/pages/arquivos/ VSGPP-\%20GT3-\%20Mirian\%20Maria\%20Kosak\%20Deivdy\%20Borges\%20 Pereira\%20e\%20Adriele\%20Andreia\%20Inacio.pdf. Acesso em: 31 jan. 2019.

LUGONES, María. Rumo a um feminismo descolonial. Estudos Feministas, v. 22, n. 3, p. 935-952, 2014. Disponível em: https://periodicos.ufsc.br/index.php/ref/article/ view/36755/28577. Acesso em: 20 ago. 2018.

NIEVA DE LA PAZ, Pilar. Autoras Dramaticas Españolas entre 1918 y 1936, Teatro y Representación. Madrid: Consejo Superior de Investigaciones Científicas, Instituto de Filosofia, 1993.

NÚCLEO DA CAROCHINHA. Liquidação de Mulheres. Calçadão 13 de maio, Campinas. 2018. Concepção: Veronica Fabrini. Foto: Veronica Fabrini.

RAGO, Margaret. Epistemologia Feminista, Gênero e História. In:PEDRO, Joana Maria; GROSSI, Miriam Pillar (org.). Masculino, Feminino, Plural. Florianópolis: Editora das 
Mulheres, 1998. p. 21-42.

ROSSI, Amanda; CARNEIRO, Julia Dias; GRAGNANI, Juliana. \#EleNão: a manifestação histórica liderada por mulheres no Brasil vista por quatro ângulos. BBC News, 30 set. 2018. Disponível em: https://www.bbc.com/portuguese/brasil-45700013. Acesso em: 30 jan. 2019.

SANDYS, Frederick. Cassandra. 1863-1864. 1 pintura, óleo sobre tela. Disponível em: https://didoofcarthage.tumblr.com/post/58352094095/cassandra-by-fredericksandys-1863-1864-oil-on. Acesso em: 12 maio 2019.

SANTOS, Boaventura de Sousa. O Colonialismo insidioso. Sul21, 2 abr. 2018. Disponível em: https://www.sul21.com.br/opiniaopublica/2018/04/o-colonialismoinsidioso-por-boaventura-de-sousa-santos/. Acesso em: 22 ago. 2018.

SEGATO, Rita Laura. In: Ciudad Juárez: de este lado del puente. Ciudad de México: Epikeia: Instituto Nacional de las Mujeres, 2004.

SOARES, Luiz Eduardo. A barbárie está autorizada. O horror saiu do armário. Sul21, 6 out. 2018. Disponível em: https://www.sul21.com.br/opiniaopublica/2018/10/abarbarie-esta-autorizada-o-horror-saiu-do-armario-por-luiz-eduardo-soares/. Acesso em: 9 out. 2018.

VINAGRE PEREIRA, Sandra. Cassandra: a voz de uma ideologia. 2013. $146 \mathrm{f}$. Dissertação (Mestrado em Estudos Clássicos) - Faculdade de Letras, Universidade de Lisboa, Lisboa, 2013. 